CZASOPISMO INŻYNIERII LA¿OWEJ, ŚRODOWISKA I ARCHITEKTURY JOURNAL OF CIVIL ENGINEERING, ENVIRONMENT AND ARCHITECTURE

JCEEA, t. XXXIV, z. 64 (1/17), styczeń-marzec 2017, s. 335-346, DOI:10.7862/rb.2017.31

\author{
Ewelina DEC ${ }^{1}$ \\ Vyacheslav PISAREV ${ }^{2}$
}

\title{
ANALIZA ŚRODOWISKA ZEWNĘTRZNEGO PRZEBYWANIA LUDZI W OKRESIE LETNIM
}

\begin{abstract}
Celem pracy jest analiza środowiska zewnętrznego przebywania ludzi w okresie letnim do otrzymania danych niezbędnych do projektowania instalacji uzdatniania powietrza w upalne dni na otwartej przestrzeni. Dane meteorologiczne zebrane na przestrzeni wielu lat jednoznacznie stwierdzają tendencję wzrostu temperatury na Ziemi. Skutki tego zjawiska są najbardziej odczuwalne przez kraje, w których temperatura powietrza w okresie letnim przekracza $30^{\circ} \mathrm{C}$, co uniemożliwia mieszkańcom normalne funkcjonowanie. Podczas takich upalnych dni niezbędny dla człowieka staje się system chłodzenia powietrza nie tylko w pomieszczeniach wewnętrznych, ale również w strefach zewnętrznych. Istotną rolę w projektowaniu systemów uzdatniania powietrza na otwartej przestrzeni odgrywa pojęcie temperatury odczuwalnej. W artykule przedstawiono zależność temperatury odczuwalnej od prędkości wiatru oraz wilgotności względnej powietrza. Z przeprowadzonej analizy wynika, iż prędkość wiatru wpływa znacząco na wartość temperatury odczuwalnej. Zależność ta odgrywa dużą rolę w systemach uzdatniania powietrza, ze względu na możliwość obniżenia wartości temperatury odczuwalnej w stosunku do rzeczywistej, za pomocą regulacji jedynie prędkości strumienia powietrza. Dodatkowo, wraz ze wzrostem wilgotności względnej powietrza, temperatura odczuwalna rośnie. Wynika z tego, że lepsze efekty chłodzenia powietrza $\mathrm{w}$ okresie letnim, uzyskamy przy niższej wilgotności względnej powietrza. Analiza procesów uzdatniania powietrza dla warunków zewnętrznych jest niezbędna. W Polsce podczas upalnych dni w większości przypadków występuje bardzo duże nasłonecznienie. Perspektywiczne jest zastosowanie technologii ochładzania powietrza z wykorzystaniem energii słonecznej.
\end{abstract}

Słowa kluczowe: klimatyzacja, wentylacja, ocieplenie klimatu, temperatura odczuwalna

\section{Wprowadzenie}

Instalacja wentylacji i klimatyzacji odgrywa istotną rolę w strefach przebywania ludzi. Celem działania tych instalacji jest zapewnienie odpowiednich

1 Autor do korespondencji / corresponding author: Vyacheslav Pisarev, Politechnika Rzeszowska, Al. Powstańców Warszawy 12, 35-959 Rzeszów, +48178651946, pisarev@ prz.edu.pl

${ }^{2}$ Ewelina Dec, Politechnika Rzeszowska, Al. Powstańców Warszawy 12, 35-959 Rzeszów, $+48178651946$ 
warunków termiczno-wilgotnościowych dla człowieka w strefie jego przebywania zarówno wewnętrznej jak i zewnętrznej.

Dane meteorologiczne zebrane na przestrzeni wielu lat jednoznacznie stwierdzają tendencję wzrostu temperatury na Ziemi. Skutki tego zjawiska są najbardziej odczuwalne przez kraje, w których temperatura powietrza w okresie letnim przekracza $30^{\circ} \mathrm{C}$, co uniemożliwia mieszkańcom normalne funkcjonowanie. Efektem ocieplenia się klimatu jest coraz częstsze występowanie zjawisk ekstremalnych, takich jak fale upałów czy susze, na co narażone są kraje, takie jak Polska, położone w strefach umiarkowanych. Podczas takich upalnych dni, niezbędny dla człowieka staje się system chłodzenia powietrza, nie tylko w pomieszczeniach wewnętrznych, ale również w strefach zewnętrznych. Należy jednak zwrócić uwagę, iż standardowy system uzdatniania powietrza zużywa duże ilości energii elektrycznej, co obciąża sieć elektryczną. Ciekawym i alternatywnym rozwiązaniem jest zastosowanie odnawialnych źródeł energii, na przykład paneli fotowoltaicznych, co jest jak najbardziej uzasadnione podczas upałów, ze względu na długotrwałe nasłonecznienie.

Celem pracy jest analiza środowiska zewnętrznego przebywania ludzi w okresie letnim do otrzymania danych niezbędnych do projektowania instalacji uzdatniania powietrza w upalne dni na otwartej przestrzeni.

\section{Wpływ stanu powietrza na zdrowie oraz komfort}

Warunki klimatyczne mają ogromny wpływ na zdrowie oraz efektywność pracy, czy odpoczynku człowieka. Jakość powietrza zależy w bardzo dużym stopniu od wilgotności oraz temperatury. Powietrze suche, chłodne człowiek odczuwa, jako świeże i czyste. Natomiast powietrze o takim samym składzie chemicznym i stopniu zanieczyszczenia, lecz o wyższej temperaturze oraz wilgotności, sprawia wrażenie nieświeżego i dusznego. Jeżeli, w celu osiągnięcia jak najlepszych warunków klimatycznych w pomieszczeniu, mamy wpływ na temperaturę oraz poziom wilgotności, to w strefach zewnętrznych, możemy mieć wpływ tylko na temperaturę. Wdychane przez człowieka powietrze ciepłe, nie jest w stanie ochłodzić organizmu w procesie konwekcji oraz odparowania. Odczucia cieplne każdego człowieka wiążą się z jego układem termoregulacji, na co, z kolei wpływa aktywność fizyczna, typ odzieży oraz parametry otoczenia człowieka [2,4].

Jeżeli przeciąg to zjawisko niepożądane, a ruchy powietrza powyżej $0,3 \div 0,5 \mathrm{~m} / \mathrm{s}$ w pomieszczeniach prowadzą do wychłodzenia ludzkiego organizmu, to na zewnątrz mówimy o innych prędkościach ruchu powietrza wywołanych wiatrem. Zagadnienia te, są w literaturze z punktu widzenia komfortu organizmu ludzkiego słabo rozpatrzone. Analizując dane pogodowe, a szczególnie wpływ wiatru na środowisko (tab. 1.) można zauważyć, że przy projektowaniu ruchu powietrza $\mathrm{w}$ strefie zewnętrznej pod działaniem instalacji wentylacyjnej prędkość strumieni powietrza nie powinna przekraczać $5 \div 5,5 \mathrm{~m} / \mathrm{s}$. Przy większych prędkościach z ziemi do powietrza zostaje podniesiony kurz $[1,12]$. 
Tab. 1. Ocena prędkości wiatru na podstawie widocznych skutków działania wg $[1,12]$

Tab. 1. Rating wind speed based on the visible effects by $[1,12]$

\begin{tabular}{|l|c|l|}
\hline \multicolumn{1}{|c|}{ Nazwa wiatru } & $\begin{array}{c}\text { Prędkość } \\
\text { wiatru } \\
{[\mathrm{m} / \mathrm{s}]}\end{array}$ & \multicolumn{1}{|c|}{ Objawy na lądzie } \\
\cline { 2 - 3 } cisza & $0 \div 0,2$ & zupełna cisza \\
\hline bardzo słaby powiew & $0,3 \div 1,5$ & dym unosi się prostopadle w górę \\
\hline słaby wiatr & $1,6 \div 3,3$ & odczuwa się istnienie powiewu; liście chwilami drżą \\
\hline łagodny wiatr & $3,4 \div 5,4$ & $\begin{array}{l}\text { liście drzew poruszają się; powierzchnia wody stojącej } \\
\text { marszczy się }\end{array}$ \\
\hline umiarkowany wiatr & $5,5 \div 7,9$ & $\begin{array}{l}\text { gałęzie drzew zaczynają się ruszać; wiatr unosi z ziemi } \\
\text { kurz i suche liście }\end{array}$ \\
\hline żywszy wiatr & $8,0 \div 10,7$ & $\begin{array}{l}\text { wyprostowują się duże flagi; poruszają się gałęzie drzew; } \\
\text { wiatr gwiżdże w uszach }\end{array}$ \\
\hline silny wiatr & $10,8 \div 13,8$ & $\begin{array}{l}\text { poruszają się grube gałęzie drzew; słychać świst wiatru } \\
\text { na przedmiotach stałych }\end{array}$ \\
\hline bardzo silny wiatr & $13,9 \div 17,1$ & $\begin{array}{l}\text { poruszają się największe gałęzie drzew; idąc pod wiatr } \\
\text { odczuwa się znaczny opór }\end{array}$ \\
\hline
\end{tabular}

Na rysunku 1 pokazano wykres, przedstawiający liczbę dni każdego miesiąca, podczas których występuje określona prędkość wiatru.

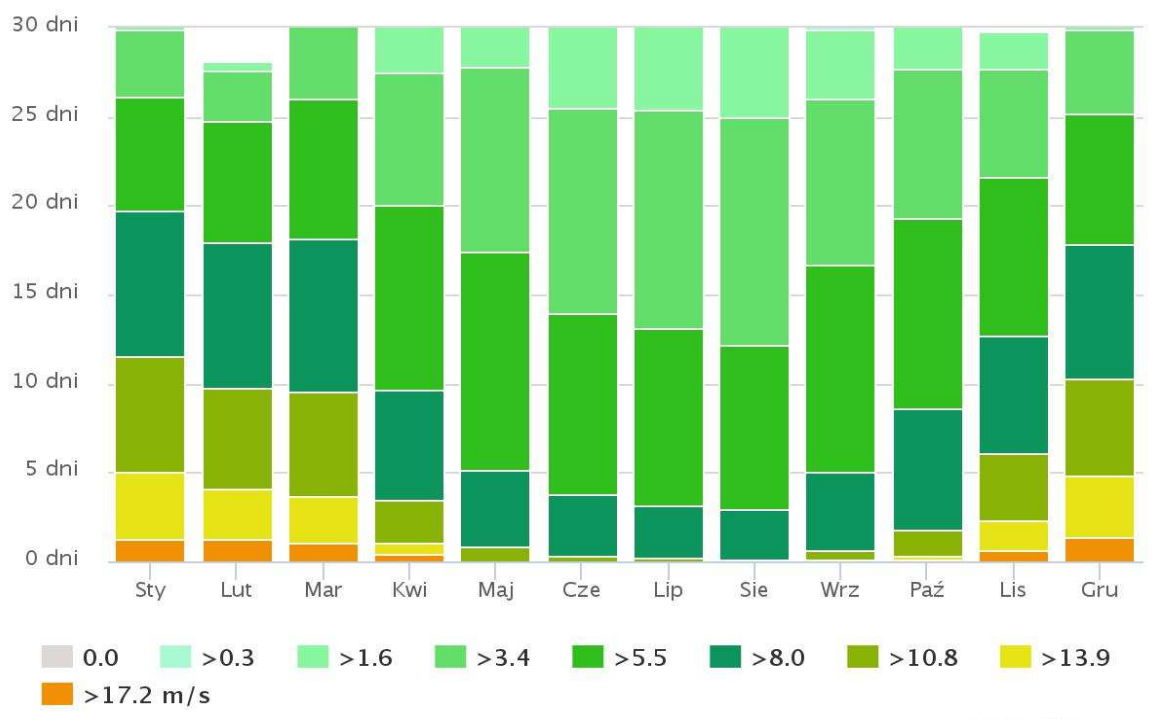

Rys. 1. Liczba dni w ciągu danego miesiąca, podczas których występuje wiatr o określonej prędkości, wykres oparty na godzinowych modelach symulacji pogody z 30 lat dla Rzeszowa, na podstawie [15]

Fig. 1. The number of days during the month, during which there is a certain wind speed, the chart based on hourly weather simulation models of 30 years for Rzeszów, based on [15] 
Na podstawie wykresu na rysunku 1, można zauważyć, że maksymalne prędkości wiatru (powyżej 17,2 m/s) mogą wystąpić w miesiącach od listopada do kwietnia. Natomiast w czasie lata, maksymalna prędkość wiatru nie przekracza $10,8 \mathrm{~m} / \mathrm{s}$. Najczęściej występujący wiatr w okresie od maja do września ma prędkość w zakresie $3,4 \div 8 \mathrm{~m} / \mathrm{s}$.

W ten sposób na samopoczucie ludzi działa wiatr, temperatura i wilgotność, co należy analizować łącznie oraz w szerszej skali dla stref zewnętrznych niż w pomieszczeniach zamkniętych.

\section{Charakterystyka klimatu w Polsce i na świecie - analiza danych meteorologicznych}

Polska leży w obszarze klimatu umiarkowanego ciepłego przejściowego, który charakteryzuje się zmiennymi stanami pogody w ciągu roku. Chociaż średnie temperatury półrocza letniego wynoszą około $18^{\circ} \mathrm{C}$, to możliwe są dni upalne w dużej ilości z temperaturami powyżej $25^{\circ} \mathrm{C}$. Najcieplejszym rejonem Polski jest część południowo-zachodnia, natomiast najchłodniejszym - północno-wschodnia część kraju i obszary górskie. Rozkład temperatury latem ma przebieg równoleżnikowy, jej wartości maleją z południa na północ, z wyjątkiem terenów górskich. Dni gorące, czyli o temperaturze maksymalnej ponad $25^{\circ} \mathrm{C}$, występują od maja do września. Ich liczba wzrasta w miarę oddalania się od morza (od 10 do ponad $40 \mathrm{dni}$ ). Absolutne maksima temperatury dochodzą prawie do $40^{\circ} \mathrm{C}[8,14]$.

$\mathrm{Na}$ podstawie wieloletnich obserwacji zmian klimatu, zauważa się dużą zmienność temperatury powietrza z każdym rokiem. Dane meteorologiczne jednoznacznie wskazują, iż klimat w Polsce ociepla się, co jest szczególnie widoczne od roku 1989 (rys.2). Na poniższym wykresie wyznaczono linię trendu, czyli funkcję liniową rosnącą, opisaną wzorem: $y=0,007 x+6,9771$, która

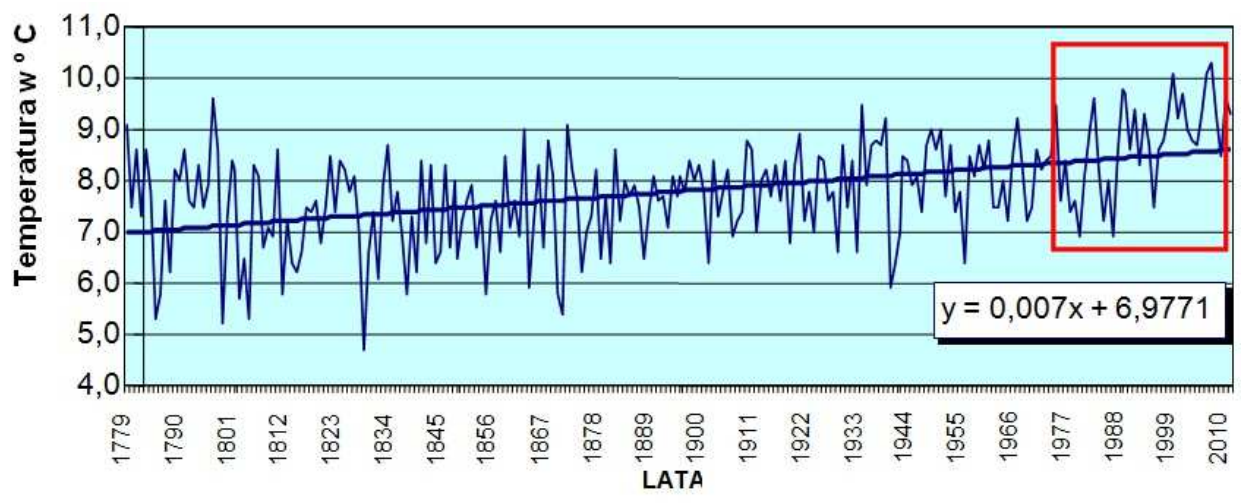

Rys. 2. Zmienność średniej rocznej temperatury w Warszawie w okresie 1779-2010, na podstawie [8]

Fig. 2. The variability of mean annual temperature in Warsaw in the period 1779-2010, based on [8] 
obrazuje charakterystykę zmiany średniej rocznej temperatury powietrza w Warszawie. Przyjęte oznaczenia: y - temperatura średnia roczna ${ }^{\circ}{ }^{\circ} \mathrm{C}, \mathrm{x}-$ lata od 1779 do 2010 [3,8].

Oczywisty jest fakt, iż z roku na rok rośnie nie tylko średnia roczna temperatura, ale i temperatura średnia okresu letniego, o czym brak danych w literaturze.

Prognozy zmian temperatury wskazują, że do końca stulecia średnia roczna temperatura powietrza w Europie wzrośnie od $2^{\circ} \mathrm{C}$ do ponad $6{ }^{\circ} \mathrm{C}$ ponad poziom $\mathrm{z}$ roku 1990. Spowoduje to wzrost poziomu morza oraz wzrost częstości występowania niekorzystnych zjawisk klimatycznych. Co ważne - wzrosną problemy ludzi związane z przebywaniem na otwartej przestrzeni, wywołane wysoką temperaturą w okresie lata, szczególnie w środkowej części dnia, kiedy temperatury są najwyższe w okresie całej doby $[3,8]$.

Największy wpływ na warunki klimatyczne wywierają zjawiska ekstremalne, których obecny wzrost liczby wystąpień zauważalnie zmienia dynamikę cech klimatu w Polsce. Do zjawisk termicznych niekorzystnych i uciążliwych dla środowiska i społeczeństwa należą fale upałów (ciągi dni z maksymalną temperaturą dobową powietrza przekraczającą $30^{\circ} \mathrm{C}$ utrzymującą się, przez co najmniej 3 dni), najczęściej występujące w południowo-zachodniej części Polski, a najrzadziej - w rejonie wybrzeża i górach, z najdłuższymi ciągami dni upalnych trwającymi przynajmniej $17 \mathrm{dni}$. Na rysunku 3 przedstawiono liczbę dni upalnych, które wystąpiły w Polsce w latach $1971-2010$. Na wykresie wyznaczono funkcję liniową y $=0,1278 \mathrm{x}+2,0848$, która charakteryzuje się rosnącą tendencją liczby dni upalnych w Polsce. Oznaczenia przyjęte na rysunku: x - kolejne lata od roku 1971 do 2010, y - liczba dni z temperaturą powietrza $\geq 30^{\circ} \mathrm{C}[8]$.

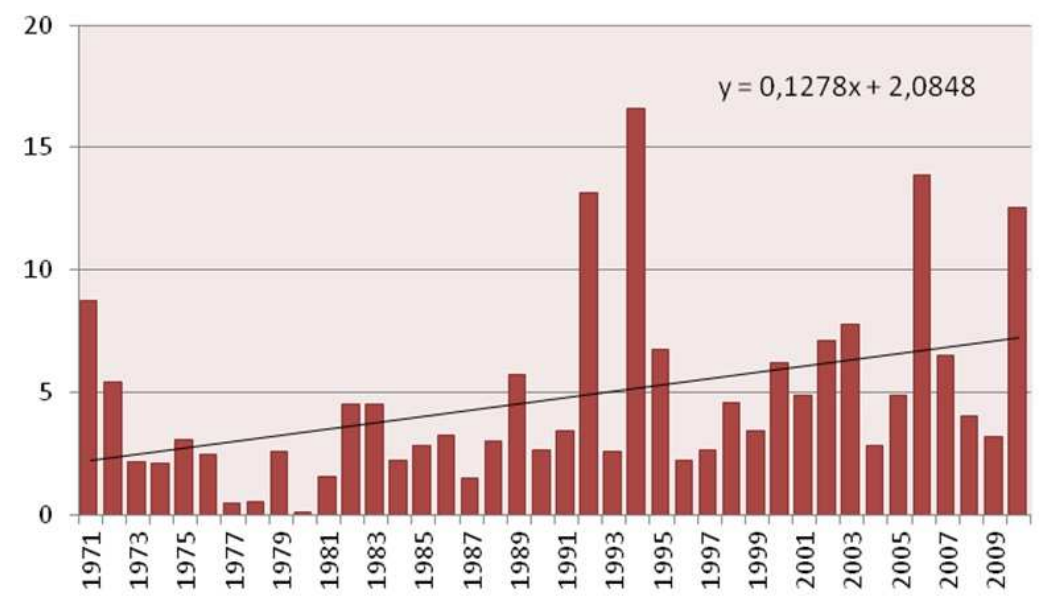

Rys. 3. Liczba dni upalnych w Polsce w okresie 1971-2010, na podstawie [8]

Fig. 3. The number of hot days in Poland in the period 1971-2010, based on [8] 
Pod względem częstości występowania dni bardzo słonecznych uprzywilejowany jest maj, natomiast obniżenie frekwencji obserwowane w czerwcu jest wywołane cyrkulacją powietrza w atmosferze Ziemi [8].

W okresie lata, podczas upalnych dni, zastosowanie systemu chłodzenia powietrza, staje się niezbędne dla prawidłowego funkcjonowania człowieka i pracy instalacji przemysłowych. Najbardziej narażone na wysokie temperatury są kraje leżące w klimacie równikowym. Ich średnie temperatury roczne sięgają $30^{\circ} \mathrm{C}$. W czołówce najgorętszych miejsc na świecie znajduje się Pustynia Lut w Iranie, libijskie miasto Al-Azizija oraz Dolina Śmierci w USA, gdzie meteorolodzy odnotowali temperaturę powietrza sięgającą $58^{\circ} \mathrm{C}$ [10].

Przykładem państwa, które standardowo zmaga się z upałami jest Katar. Średnia temperatura powietrza w ciągu roku wynosi tam $26^{\circ} \mathrm{C}$. Katar jest państwem o klimacie pustynnym, opadów nie ma praktycznie przez cały rok. W okresie od marca do października temperatura powietrza przekracza $30^{\circ} \mathrm{C}$, niekiedy sięgając nawet $50^{\circ} \mathrm{C}$ [3]. Sposobem na przetrwanie uciążliwych upałów jest dla Katarczyków odpowiednie osłonienie ciała przed promieniowaniem słonecznym. Noszenie długich przewiewnych strojów oraz nakrycie głowy, chroni przed szczególnie groźnym w tamtych rejonach promieniowaniem słonecznym. Specjalna konstrukcja budynków pozwala na utrzymanie stosunkowo niskiej temperatury powietrza, poprzez zastosowanie bardzo małych otworów okiennych, ograniczających przenikanie słońca do wnętrza. W ciągu dnia w Katarze, przede wszystkim w południe, nie jest bezpieczne dla człowieka przebywanie bezpośrednio w strefie zewnętrznej. Długotrwały marsz, lub praca fizyczna to olbrzymi wysiłek, grożący udarem cieplnym, dlatego należy go unikać. Katarczycy poruszają się o tej porze dnia przede wszystkim klimatyzowanymi samochodami, ograniczając przebywanie na słońcu. Na świeżym powietrzu można spotkać jedynie turystów lub też ciężko pracujących fizycznie ludzi biedniejszych. Wszelkie targowiska są zadaszone, a domy, urzędy czy budynki użyteczności publicznej wyposażone w klimatyzację. W Katarze często spotykane są na publicznych placach czy w parkach fontanny zraszające powietrze, które stanowią swoistą strefę chłodu.

Obecny trend zmiany klimatu spowoduje wzrost temperatury na całym świecie. Chłodzenie powietrza niezbędne będzie nie tylko w miejscach długotrwałego przebywania człowieka, lecz w każdym miejscu, w strefach zewnętrznych. Stanowić to jednak może duże wyzwanie dla obecnie stosowanych systemów chłodzenia powietrza, ze względu na bardzo duże zyski ciepła i tym samym niezbędną wysoką ich wydajność.

Wzrost temperatury przyczyni się do zwiększenia zapotrzebowania na energię elektryczną wykorzystywaną do celów chłodzenia powietrza. Taki wzrost zapotrzebowania z jednoczesnym ograniczeniem produkcji na przykład w elektrowniach wodnych z powodu zmniejszonych zasobów i ograniczoną dostępnością wody do chłodzenia w elektrowniach, może powodować zakłócenia $\mathrm{w}$ dostawach energii elektrycznej. 


\section{Temperatura odczuwalna}

Na podstawie badań wpływu czynników atmosferycznych takich jak temperatura, wilgotność względna, wiatr, określono pojęcie temperatury odczuwalnej.

Temperatura odczuwalna jest to stan, który określa, jakie odczucie termiczne wystąpi przy danych warunkach pogodowych. Pojęcie temperatury odczuwalnej zostało zdefiniowane przez Paula A. Sple i Charlesa F. Passela w latach czterdziestych ubiegłego wieku. Podczas badań na Antarktydzie naukowcy sprawdzali ile czasu potrzeba, aby woda w plastikowym cylindrze zamarzła (na otwartej przestrzeni). Wykazano, że czas ten zależy od temperatury początkowej wody, wysokości temperatury panującej na zewnątrz oraz od prędkości wiatru. W warunkach dużej wilgotności względnej temperatura zmierzona (statyczna) może być odbierana przez organizm człowieka, jako niższa. Podobnie, ale dużo wyraźniej, zmienia się odczuwanie temperatury w warunkach zwiększonego przepływu powietrza, na przykład w przestrzeniach, w których pracują klimatyzatory, nawiewające powietrze chłodne z prędkością powyżej $0,2 \mathrm{~m} / \mathrm{s}[2,15]$.

Należy pamiętać, że większość propozycji na obliczenie temperatury odczuwalnej nie uwzględnia jak grubo jest ktoś ubrany, czy dana osoba siedzi czy ćwiczy, czy świeci słońce, jak szybko ktoś oddycha (szybki oddech może być przyczyną strat ciepła). Do wyznaczenia temperatury odczuwalnej może być zastosowany kalkulator temperatury odczuwalnej skonstruowany przez Katedrę Meteorologii i Klimatologii Uniwersytetu Warmińsko-Mazurskiego [13]. Wykorzystane w nim wzory wyznaczone zostały dla południowego terminu obserwacji. Pora południowa jest uważana przez wielu autorów, jako najbardziej reprezentatywna pod względem warunków pogodowych, jakie występują w ciągu dnia o największej aktywności fizycznej człowieka [5].

Wilgotność względna to stosunek ilości pary wodnej w powietrzu do ilości pary wodnej potrzebnej do nasycenia powietrza przy danej temperaturze, wyrażony w procentach. Powietrze w zależności od temperatury, może w sobie pomieścić konkretną ilość wilgoci (pary wodnej). Im wyższa jest temperatura powietrza, tym więcej zawiera pary wodnej. Natomiast im jest ono zimniejsze tym mniej. Ilość ta jest ściśle określona dla każdej temperatury. Wilgotność powietrza zmienia się $\mathrm{w}$ procesie podgrzewania oraz chłodzenia.

Na rysunku 4 przedstawiono średnie roczne wieloletnie wartości wilgotności względnej powietrza, występujące w mieście Legionowo [16].

$\mathrm{Z}$ wykresu na rysunku 4, wynika, że najniższa średnia wilgotność względna powietrza występuje w okresie lata $(67 \%)$.

Wilgotność w znacznym stopniu wpływa na warunki komfortu cieplnego, ponieważ człowiek oddaje ciepło przez parowanie. Intensywność parowania zależy w tych samych warunkach od różnicy ciśnienia cząstkowego pary wodnej na powierzchni skóry i pary wodnej zawartej w powietrzu. Np. w temperaturze $20^{\circ} \mathrm{C}$ oddawanie ciepła przez parowanie nie odgrywa wielkiej roli. W tej temperaturze również wilgotność powietrza nie ma dużego wpływu na warunki komfortu cieplnego. Natomiast wyższa temperatura powietrza sprawia, że wil- 


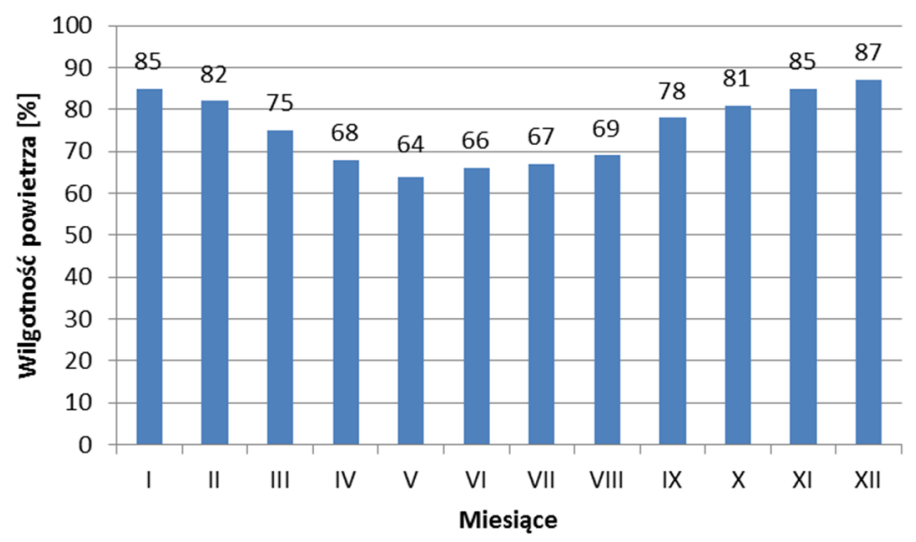

Rys. 4. Średnia roczna wieloletnia wilgotność względna powietrza zewnętrznego odnotowana w mieście Legionowo, opracowano na podstawie [16]

Fig. 4. The average annual long-term relative humidity of the outside air recorded in Legionowo, developed on the basis of [16]

gotność względna powietrza zaczyna nabierać decydującego znaczenia. Wilgotność względna powietrza, mieszcząca się w granicach $30 \div 60 \%$ ma niewielki wpływ na odczucia cieplne człowieka. Jednak dla wilgotności względnej powyżej 70\%, wilgoć może lekko wykraplać się na zimnych elementach [11].

Przeprowadzono obliczenia temperatury odczuwalnej w zależności od rzeczywistej temperatury powietrza przy różnych prędkościach wiatru i wilgotności powietrza, na podstawie kalkulatora temperatury odczuwalnej [13].

Na podstawie opracowanych wykresów (rys. 5-9) wyraźnie widać, że decydujący wpływ na wartość temperatury odczuwalnej ma prędkość wiatru.

\section{Czynnik chłodzący wiatru dla wilgotności względnej powietrza $\phi=45 \%$}

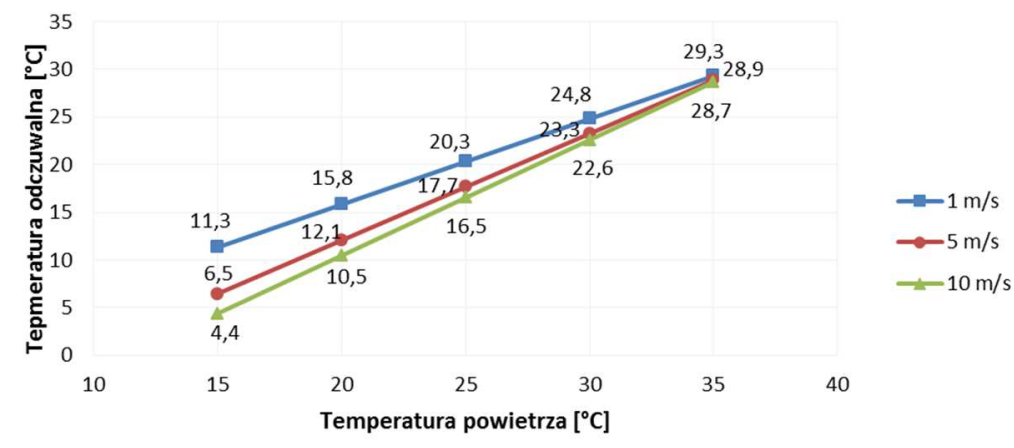

Rys. 5. Zależność temperatury odczuwalnej oraz temperatury powietrza od prędkości wiatru przy wilgotności powietrza $\varphi=45 \%$, opracowano na podstawie [13]

Fig. 5. The dependence of wind chill and the temperature of the air on the wind speed at a humidity of $\varphi=45 \%$, developed on the basis of [13] 
W miarę nasilania się wiatru, temperatura odczuwalna spada. Oczywiście różnica ta zależy od rzeczywistej temperatury powietrza. Im temperatura powietrza jest wyższa, różnica zmniejsza się. Na przykład, przy wilgotności powietrza $45 \%$, dla temperatury atmosferycznej $20^{\circ} \mathrm{C}$, przy wietrze o prędkości $1 \mathrm{~m} / \mathrm{s}$, temperatura odczuwalna wynosi $15,8^{\circ} \mathrm{C}$. Natomiast przy prędkości wiatru równej $10 \mathrm{~m} / \mathrm{s}$, temperatura odczuwana przez człowieka to $10,5^{\circ} \mathrm{C}$.

\section{Czynnik chłodzący wiatru dla wilgotności względnej powietrza $\phi=80 \%$}

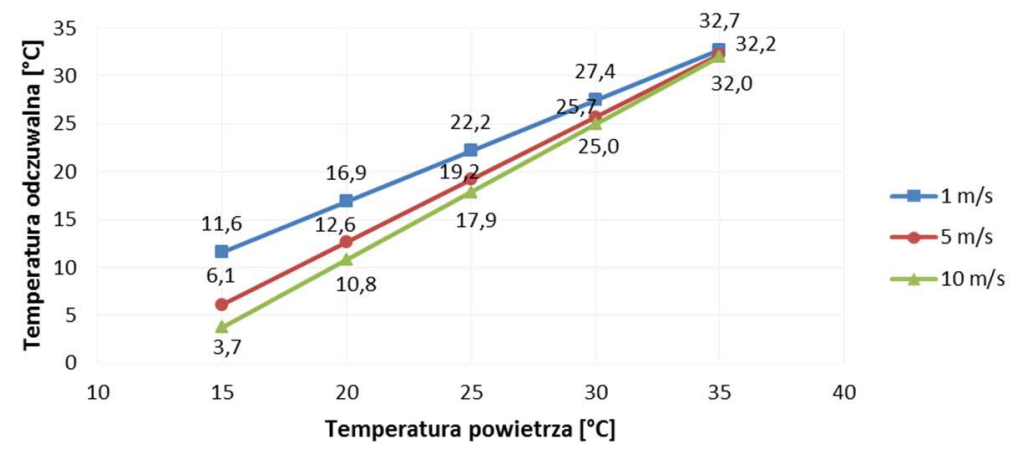

Rys. 6. Zależność temperatury odczuwalnej oraz temperatury powietrza od prędkości wiatru przy wilgotności powietrza $\varphi=80 \%$, opracowano na podstawie [13]

Fig. 6. The dependence of wind chill and the temperature of the air on the wind speed at a humidity of $\varphi=80 \%$, developed on the basis of [13]

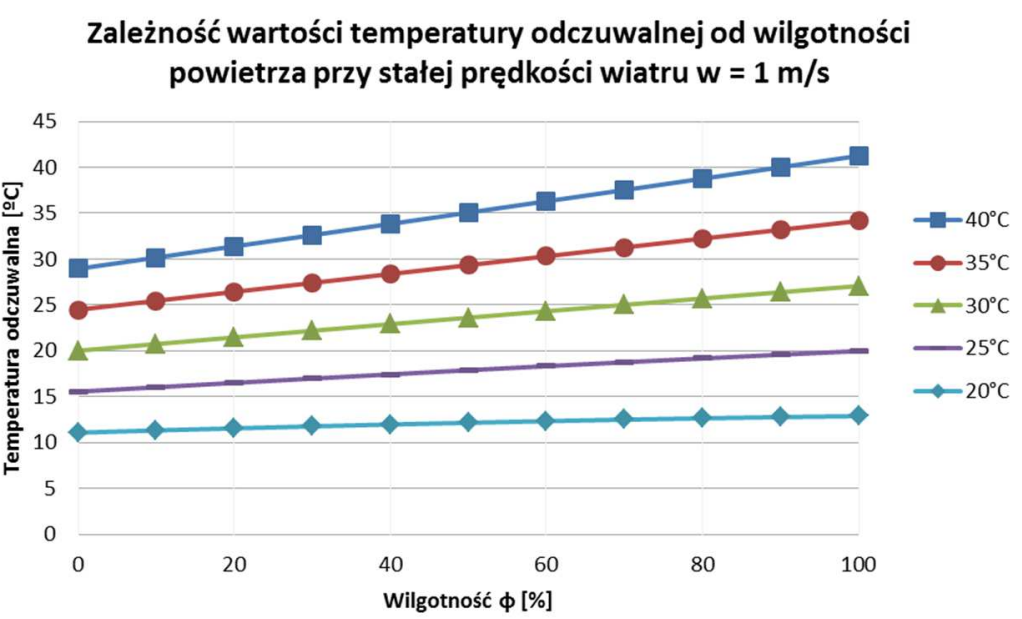

Rys. 7. Zależność wartości temperatury odczuwalnej od wilgotności powietrza przy prędkości wiatru równej $1 \mathrm{~m} / \mathrm{s}$, opracowano na podstawie [13]

Fig. 7. Temperature dependence of the humidity of the cooling wind speed equal to $1 \mathrm{~m} / \mathrm{s}$ is adjusted [13] 
Zależność wartości temperatury odczuwalnej od wilgotności powietrza przy stałej prędkości wiatru $w=5 \mathrm{~m} / \mathrm{s}$

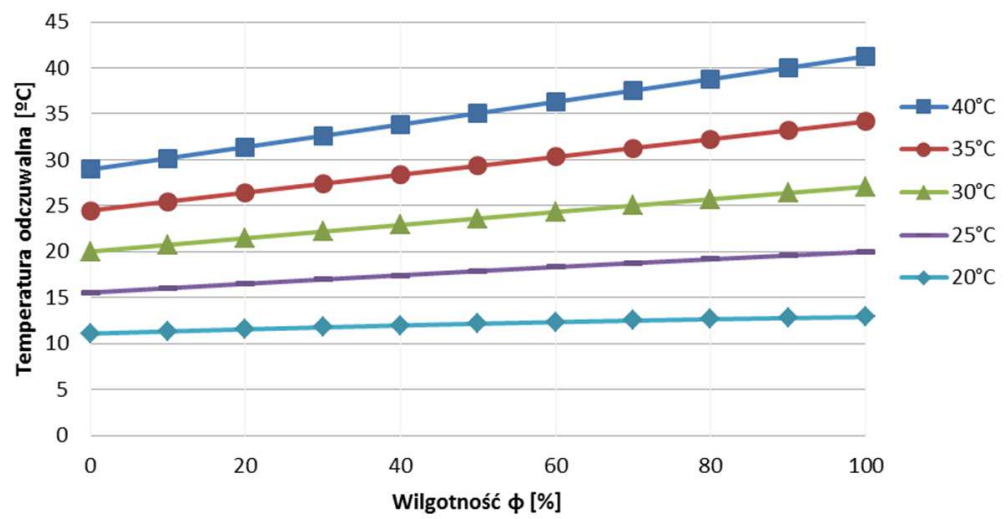

Rys. 8. Zależność wartości temperatury odczuwalnej od wilgotności powietrza przy prędkości wiatru równej $5 \mathrm{~m} / \mathrm{s}$, opracowano na podstawie [13]

Fig. 8. Temperature dependence of the humidity of the cooling wind speed equal to $5 \mathrm{~m} / \mathrm{s}$ is adjusted [13]

Zależność wartości temperatury odczuwalnej od wilgotności powietrza przy stałej prędkości wiatru $w=10 \mathrm{~m} / \mathrm{s}$

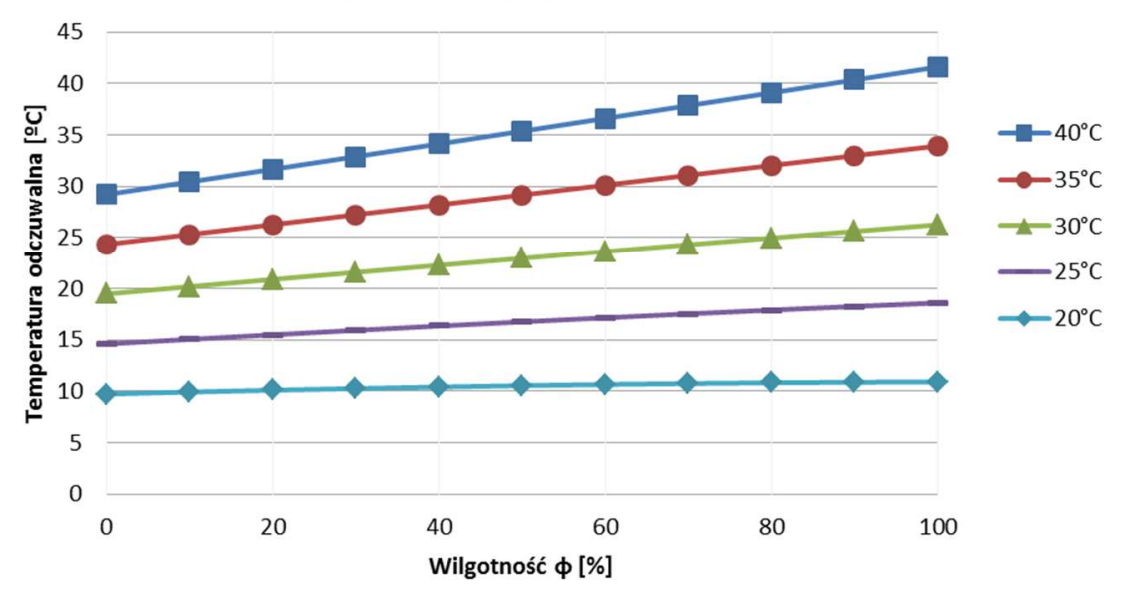

Rys. 9. Zależność wartości temperatury odczuwalnej od wilgotności powietrza przy prędkości wiatru równej $10 \mathrm{~m} / \mathrm{s}$, opracowano na podstawie [13]

Fig. 9. Temperature dependence of the humidity of the cooling wind speed equal to $10 \mathrm{~m} / \mathrm{s}$ is adjusted [13]

Istotnym czynnikiem warunkującym wartość temperatury odczuwalnej jest wilgotność powietrza. Warto zaznaczyć, że dla temperatury powietrza wyższej niż $35^{\circ} \mathrm{C}$ przy jednocześnie wysokiej wilgotności względnej, temperatura od- 
czuwalna może być nawet wyższa od rzeczywistej temperatury powietrza, nawet przy wietrze o prędkości $10 \mathrm{~m} / \mathrm{s}$. Zjawisko to jest niekorzystne z punktu widzenia komfortu przebywania dla człowieka. Wynika z tego, że lepsze efekty chłodzenia powietrza w okresie letnim, uzyskamy przy niższej wilgotności względnej powietrza.

Na podstawie powyższej analizy stwierdzono, iż prędkość wiatru wpływa znacząco na wartość temperatury odczuwalnej. Zależność ta odgrywa dużą rolę w systemach uzdatniania powietrza, ze względu na możliwość obniżenia wartości temperatury odczuwalnej w stosunku do rzeczywistej, za pomocą regulacji jedynie prędkości strumienia powietrza. Odpowiednia prędkość strugi nawiewanego powietrza, tak jak prędkość wiatru, obniży temperaturę odczuwalną przez człowieka o zadaną wartość, bez obniżenia temperatury nawiewu.

\section{Wnioski}

1. Na skutek wysokich temperatur zewnętrznych podczas dni upalnych oraz zmiany klimatu ze wzrostem temperatury w okresie letnim, ważne jest opracowanie technologii ochładzania powietrza w wybranych lokalnych strefach zewnętrznych przebywania ludzi (odpoczynku, pracy).

2. Technologie ochładzania powietrza strefy zewnętrznej przebywania ludzi powinny być uzupełnione $\mathrm{w}$ sposoby zmniejszenia obciążenia cieplnego, a właściwie ochronę od nasłonecznienia, zacienienie itp.

3. Efektywne są systemy chłodzenia wyparnego w obszarze stref zewnętrznych przebywania ludzi.

4. Analiza procesów uzdatniania powietrza dla warunków zewnętrznych jest niezbędna. Ciekawym jest określenie wpływu wiatru i wilgotności z wykorzystaniem wykresu i-x powietrza wilgotnego.

5. Ważnym może być analiza wykorzystania strumieni powietrza różnych nawiewników, miejsca ich usytuowania, których wpływ może być decydujący.

6. W Polsce w upalne dni w większości przypadków występuje bardzo duże nasłonecznienie. Dla ochładzania powietrza perspektywiczne jest wykorzystanie technologii ochładzania powietrza na podstawie energii słonecznej.

\section{Literatura}

[1] Błażejczyk K.: Bioklimatyczne uwarunkowania rekreacji i turystyki w Polsce. Warszawa 2014.

[2] Fanger P.O., Popiołek Z., Wargocki P.: Środowisko wewnętrzne. Wpływ na zdrowie, komfort i wydajność pracy, Gliwice 2003.

[3] Lorenc H.: Atlas klimatu Polski, Instytut Meteorologii i Gospodarki Wodnej. Warszawa 2005.

[4] Raczkowski A., Skwarczyński M., Połednik B.: Ocena komfortu cieplnego w pomieszczeniu dydaktycznym wentylowanym naturalnie. 
[5] Wereski S.: Klimat odczuwalny Leska na podstawie normalnej temperatury efektywnej (NTE) i temperatury radiacyjno-efektywnej (TRE). Lublin 2009.

[6] http://www.instalacjebudowlane.pl/6217-26-76-prawidlowa-wilgotnosc-powietrza-wdomu-i-mieszkaniu.html (10.09.2016 r.).

[7] http://klimada.mos.gov.pl/adaptacja-do-zmian-klimatu/globalne-procesy/ (25.06.2016 r.).

[8] http://klimada.mos.gov.pl/zmiany-klimatu-w-polsce/tendencje-zmian-klimatu/ (25.06.2016 r.).

[9] http://www.medchitalka.ru/kostno-sustavnoy/1070/577/31434 (29.06.2016 r.).

[10] http://gadzetomania.pl/6582,gdzie-jest-najgoretsze-miejsce-na-ziemi_(29.06.2016 r.).

[11] http://www.ecoprius.pl/technika-klimatyzacyjna-i-wentylacyjna-z-rekuperacj /zadania-uzdatniania-powietrza.html (25.06.2016 r.).

[12] http://www.mojapogoda.com/leksykon-meteorologiczny/wiatr.html_(29.06.2016 r.).

[13] http://www.uwm.edu.pl/wksir/zmetkli/calcul1.htm (10.12.2015 r.).

[14] http://www.twojapogoda.pl/wiadomosci/112737,klimat-w-polsce-szybko-sie-ociepla (20.01.2016 r.).

[15] https://www.meteoblue.com/pl/pogoda/prognoza/modelclimate/rzesz\%c3\%b3w_pols ka_759734 (29.09.2016 r.).

[16] http://www.legionowo.pl/pl/strefa-mieszkanca-srodowisko-klimat (12.09.2016 r.).

\section{ANALYSIS OF EXTERNAL ENVIRONMENT PEOPLE PRESENT DURING THE SUMMER}

\section{S u m m a r y}

The aim of the study is to analyze the external environment occupied during the summer to obtain the data necessary for the design of air purification systems on hot days in the open air. Meteorological data collected over many years, clearly state the trend of temperature increase on Earth. The effects of this phenomenon are most felt by the countries in which the air temperature in summer exceeds $30^{\circ} \mathrm{C}$, which prevents the normal functioning of the residents. During such hot days necessary for man is an air cooling system, not only indoors, but also in the outer zones. An important role in the design of air purification systems for the open space concept plays a perceptible temperature. The paper shows the relationship between perceptible temperature wind speed and relative humidity. The analysis shows that the wind speed significantly affect the value of the perceptible temperature. This relationship plays an important role in the air treatment system, because the possibility of lowering the temperature of chill of the actual, only by controlling the speed of the air flow. In addition, with increasing relative humidity, wind chill increases. It follows that the better the effects of air cooling in the summer, get maintaining a lower relative humidity. Analysis of process air treatment for external conditions is essential. In Poland, during the hot days in most cases there is a very high insolation. Perspective is the use of air cooling technology using solar energy.

Keywords: air conditioning, ventilation, warming, perceptible temperature

Przestano do redakcji: $15.01 .2017 \mathrm{r}$.

Przyjęto do druku: 31.03.2017 r. 